\title{
Free radical scavenging and antioxidant enzyme fortifying activities of extracts from Smilax china root
}

\author{
Si Eun Lee ${ }^{1}$, Eun Mi Ju${ }^{1}$ and Jeong Hee $\mathrm{Kim}^{1,2}$ \\ ${ }^{1}$ Department of Oral Biochemistry, College of Dentistry, \\ Kyung Hee University, Seoul 130-701, Korea \\ ${ }^{2}$ Corresponding author: Tel, +82-2-961-0915; Fax, +82-2-960-1457, \\ E-mail, jhkimh@khu.ac.kr
}

Accepted 4 December 2001

Abbreviations: DPPH, 1,1-diphenyl-2-picrylhydrazyl; SOD, superoxide dismutase; CAT, catalase; GPX, glutathione peroxidase

\begin{abstract}
The extract from Smilax china root has been used as medicinal remedy and reported to retain antimicrobial and antimutagenic acitivities. In this study, a possible presence of antioxidant activity of Smilax china root extract was investigated. Methanol extract $(\mathrm{Me})$ revealed the presence of high 1,1-diphenyl-2-picrylhydrazyl (DPPH) free radical scavenging activity $\left(\mathrm{IC}_{50} 7.4 \mu \mathrm{g} / \mathrm{ml}\right)$ and protective property of cell's viability. Further fractionation with various solvent extraction and assay showed high levels of DPPH free radical scavenging activity in the ethyl acetate, butanol and water extracted fractions. In addition, V79-4 cells treated with Me of Smilax china root induced an increase of superoxide dismutase, catalase and glutathione peroxidase activities in a dose-dependent manner between 4-100 $\mu \mathrm{g} / \mathrm{ml}$. These results suggest that the medicinal component of the root of Smilax china extracts also contains antioxidant activity.
\end{abstract}

Keywords: Antioxidant activity, antioxidant enzymes, lipid peroxidation, radical scavenging, Smilax china root

\section{Introduction}

The reactive oxygen species (ROS) such as $\mathrm{O}_{2}^{-}, \mathrm{OH}^{-}$ and $\mathrm{H}_{2} \mathrm{O}_{2}$, together with unstable intermediates in the peroxidation of lipids are well known inducer of cellular and tissue pathogenesis leading to numerous disease states including cardiovascular disease (Witztum, 1993) and age-related degenerative conditions (Finkel and Holbrook, 2000). Neurodegenerative diseases such as
Alzheimer's disease (Richardson, 1993) and cancer (Borek, 1991) are also linked to damage from ROS as a result of an imbalance between the rate of generation of radicals and scavenging of radicals.

The cellular radical-scavenging systems include the enzymes such as superoxide dismutase (SOD), which scavenges the superoxide ion by speeding up its dismutation, catalase (CAT), a haeme enzyme, which removes hydrogen peroxide and glutathione peroxidase (GPX), a selenium-containing enzyme, which scavenges other peroxides as well as hydrogen peroxide (Blake et al., 1987). Other molecules that can counteract ROS include glutathione, flavonoids, ubiquinol-10, glucose and albumin (Halliwell and Gutteridge, 1998). The discovery by McCord and Fridovich (1969) of the SOD activity of erythrocuprein together with the finding that almost all mammalian cells contain SOD suggests the physiological importance of at least the central ROS, superoxide. External sources of antioxidative protection include antioxidant vitamins $C, E, \beta$-carotene and carotenoids as well as minerals such as selenium and zinc (Halliwell and Gutteridge, 1998).

Great efforts have been made in an attempt to find safe and potent natural antioxidants from plant resources. These include seeds (Deiana et al., 1999), beans (Duh et al., 1997), herbs (Kitts et al., 2000), tea (RoedigPenman and Gordon, 1997), berry crops (Wang and Jiao, 2000), Ginkgo biloba (Gohil et al., 2000), Panax ginseng (Keum et al., 2000) and fruits and vegetables (Cao et al., 1996; Wang et al., 1996; Brown and RiceEvans, 1998). In this study, Smilax china was selected based on its traditional use in Chinese medicine for inflammatory diseases and ischuria. Several reports describe the antimicrobial activity (Song et al., 1998) and antimutagenic activity (Lee and Lin, 1988) of this medicinal plant. Song et al. (1998) showed methanol, chloroform, ethyl acetate and butanol extracts of Smilax china exhibited potent antimicrobial activities. The extracts of Smilax china inhibited the mutagenicity of benzo[a]pyrene (Lee and Lin, 1988). However, little research has been done on antioxidant activity of this plant.

In the present study, the antioxidative actions of extract from Smilax china root are evaluated by their abilities to scavenge 1,1-diphenyl-2-picrylhydrazyl (DPPH) free radicals, protect cell viability, and inhibit the formation of lipid peroxides. The effect of extracts from Smilax china root on the activity of antioxidant enzymes such as SOD, CAT and GPX was also investigated. 


\section{Materials and Methods}

\section{Preparation of plant extracts}

The root of Smilax china $(100 \mathrm{~g})$ extracted for $3 \mathrm{~h}$ in $70 \%$ methanol at $80^{\circ} \mathrm{C}$ was filtered, concentrated with a vacuum rotary evaporator (Eyela, Japan) under the reduced pressure, and freeze-dried (Ilsin, Korea). This methanol extract (ME) was kept at $-70^{\circ} \mathrm{C}$. The methanol extract was further fractionated by additional extraction with n-hexane, dichloromethane, ethyl acetate and nbutanol, in a stepwise manner. Solvent fractions from each step were removed by rotary evaporation. The extract powder(s) was dissolved in dimethyl sulfoxide (DMSO) and diluted with phosphate buffered saline (PBS, $\mathrm{pH}$ 7.4) to give final concentrations in the range of 0.8 to $100 \mu \mathrm{g} / \mathrm{ml}$.

\section{Cell culture}

Chinese hamster lung fibroblast, V79-4 (ATCC CCL-93) cells were maintained at $37^{\circ} \mathrm{C}$ in an incubator with a humidified atmosphere of $5 \% \mathrm{CO}_{2} / 95 \%$ air. Cells were cultured in Dulbecco's modified Eagle's medium (DMEM, Gibco BRL, USA) containing $5 \%$ fetal bovine serum (FBS, BioWhittaker, USA), $100 \mu \mathrm{g} / \mathrm{ml}$ of streptomycin, 100 unit/ml of penicillin (Gibco BRL) and $2 \mathrm{mM} \mathrm{L-}$ glutamine (Gibco BRL).

\section{Measurements of antioxidant activity}

$D P P H$ free radical scavenging activity

In order to measure antioxidant activity, DPPH free radical scavenging assay was carried out as described by Blosi (1958). Methanol extract (ME) and solvent extracted fractions (SEF) of Smilax china root at various concentrations $(0.8,4,20$, and $100 \mu \mathrm{g} / \mathrm{ml})$ were added to a solution of $1.5 \times 10^{-4} \mathrm{M}$ DPPH (Sigma, USA) in methanol and the reaction mixture was shaken vigorously. The amount of DPPH remaining was determined at $520 \mathrm{~nm}$, and the radical scavenging activity was obtained from the equation:

$$
\begin{aligned}
& \text { Radical scavenging activity }(\%) \\
& \quad=\left\{\left(O D_{\text {control }}-O D_{\text {sample }}\right) / O D_{\text {control }}\right\} \times 100
\end{aligned}
$$

The antioxidant activity of Smilax china root extract was expressed as $I C_{50}$. The $I C_{50}$ value was defined as the concentration $(\mu \mathrm{g} / \mathrm{ml})$ of the extract required for inhibiting the formation of DPPH radical by $50 \%$.

\section{Cell viability}

Cell viability was estimated by the MTT assay, which is based on the cleavage of the tetrazolium salt by mitochondrial dehydrogenases in viable cells (Hansen et al., 1989). V79-4 cells were seeded in a 96 well plate at a concentration of $1.2 \times 10^{4}$ cells / well and incubated for $16 \mathrm{~h}$. After treatment with various concentrations of
$\mathrm{ME}(4,20$ and $100 \mu \mathrm{g} / \mathrm{ml}$, respectively) and $100 \mathrm{mM}$ $\mathrm{H}_{2} \mathrm{O}_{2}$ was added to the culture $1 \mathrm{~h}$ later. Cells were incubated for an additional $24 \mathrm{~h}$ at $37^{\circ} \mathrm{C}$. During the last $4 \mathrm{~h}$, cells were incubated with $20 \mu \mathrm{l}$ of MTT stock solution $(5 \mathrm{mg} / \mathrm{ml})$ in $200 \mu \mathrm{l}$ medium at $37^{\circ} \mathrm{C}$. Samples were then extracted with acidic isopropanol and the absorbance was measured with the ELISA reader (BioRad, USA) at $570 \mathrm{~nm}$. The relative cell viability was determined by the amount of MTT converted to the insoluble formazan salt. The data are expressed as mean percentage of viable cells as compared to the respective control cultures.

\section{Lipid peroxidation inhibitory activity}

Lipid peroxidation was assayed by the measurement of malondialdehyde (MDA) according to the method of Ohkawa et al. (1979). The cells were exposed to ME of Smilax china root at various concentrations $(4,20$ and $100 \mu \mathrm{g} / \mathrm{ml}$ ) in the incubation medium for $60 \mathrm{~min}$, followed by $1 \mathrm{mM}$ of $\mathrm{H}_{2} \mathrm{O}_{2}$ for 60 min. Cells were then washed with cold PBS, scraped and homogenized in ice-cold $1.15 \% \mathrm{KCl}$. Samples containing $100 \mu \mathrm{l}$ of cell lysates were combined with $0.2 \mathrm{ml}$ of $8.1 \%$ SDS, $1.5 \mathrm{ml}$ of $20 \%$ acetic acid adjusted to $\mathrm{pH} 3.5$ and $1.5 \mathrm{ml}$ of $0.8 \%$ thiobarbituric acid. The mixture was brought to a final volume of $4.0 \mathrm{ml}$ with distilled water and heated to $95^{\circ} \mathrm{C}$ for $120 \mathrm{~min}$. After cooling to room temperature, 5.0 $\mathrm{ml}$ of a mixture of $\mathrm{n}$-butanol and pyridine $(15: 1, \mathrm{v} / \mathrm{v})$ was added to each sample and the mixture was shaken vigorously. After centrifugation at $1500 \mathrm{rpm}$ for $10 \mathrm{~min}$, the supernatant fraction was isolated and the absorbance was measured at $532 \mathrm{~nm}$. Inhibitory activity towards lipid peroxidation was expressed as $I_{50}$.

\section{Assays for antioxidant enzymes}

The cells were treated with 4,20 and $100 \mu \mathrm{g} / \mathrm{ml}$ of ME of Smilax china root for $60 \mathrm{~min}$. The cells were then lysed in a lysis buffer appropriate for the requirements of each assay, as described below. The method of Bradford (1976) was used to determine protein concentrations. Results are expressed as enzyme activity per mg protein compared with corresponding control cultures.

\section{Superoxide dismutase (SOD) activity}

SOD activity was assayed by the nitroblue tetrazolium (NBT) method of Beauchamp and Fridovich (1971). NBT is reduced to blue formazan by $\mathrm{O}_{2}^{-}$, which has a strong absorbance at $560 \mathrm{~nm}$. The presence of SOD inhibits this reaction. The cells were homogenized in $0.05 \mathrm{M}$ sodium carbonate buffer $(\mathrm{pH} 10.2)$. The assay mixture consisted of $0.05 \mathrm{M}$ sodium carbonate buffer $(\mathrm{pH} 10.2)$ containing $3 \mathrm{mM}$ xanthine, $0.75 \mathrm{mM}$ NBT, $3 \mathrm{mM}$ EDTA, $1.5 \mathrm{mg} / \mathrm{ml} \mathrm{BSA}$ and $50 \mu \mathrm{l}$ of homogenate. The reaction was initiated by the addition $50 \mu \mathrm{l}$ of xanthine oxidase $(0.1 \mathrm{mg} / \mathrm{ml})$ and incubated for $30 \mathrm{~min}$ at room tempar- 
ature. The reaction was stopped by adding $6 \mathrm{mM} \mathrm{CuCl}_{2}$ and centrifuged at $1,500 \mathrm{rpm}$ for $10 \mathrm{~min}$. The absorbance of blue formazan in the supernatants was measured at $560 \mathrm{~nm}$.

\section{Catalase (CAT) activity}

The reaction mixture contained $12 \mu \mathrm{l}$ of $3 \%(\mathrm{v} / \mathrm{v}) \mathrm{H}_{2} \mathrm{O}_{2}$ and $100 \mu \mathrm{l}$ of cell lysates in $50 \mathrm{mM}$ phosphate buffer $(\mathrm{pH} \mathrm{7.0)}$ at a final volume of $1.0 \mathrm{ml}$. Samples were incubated at $37^{\circ} \mathrm{C}$ for $2 \mathrm{~min}$ and the absorbance of the samples were monitored for $5 \mathrm{~min}$ at $240 \mathrm{~nm}$. The change in absorbance is proportional to the breakdown of $\mathrm{H}_{2} \mathrm{O}_{2}$ (Carrillo et al., 1991).

\section{Glutathione peroxidase (GPX) activity}

GPX was assayed by the method of Paglia and Valentine (1967). The reaction mixture contained $0.1 \mathrm{M}$ phosphate buffer ( $\mathrm{pH}$ 7.0), $1 \mathrm{mM}$ EDTA, $10 \mathrm{mM}$ glutathione (GSH), $1 \mathrm{mM} \mathrm{NaN}_{3}, 1$ unit of glutathione reductase, 1.5 $\mathrm{mM}$ NADPH and $0.1 \mathrm{ml}$ of cell lysate. After incubation for $10 \mathrm{~min}$ at $37^{\circ} \mathrm{C}, \mathrm{H}_{2} \mathrm{O}_{2}$ was added to each sample at a final concentration of $1 \mathrm{mM}$. GPX activity was measured as the rate of NADPH oxidation at $340 \mathrm{~nm}$.

\section{Results}

Antioxidant activity of methanol extract (ME) and other solvent extracted fractions (SEF) of Smilax china root

The antioxidant activities of Smilax china root extract were examined by DPPH free radical scavenging activity, the protective effect on cell viability, and inhibition of lipid

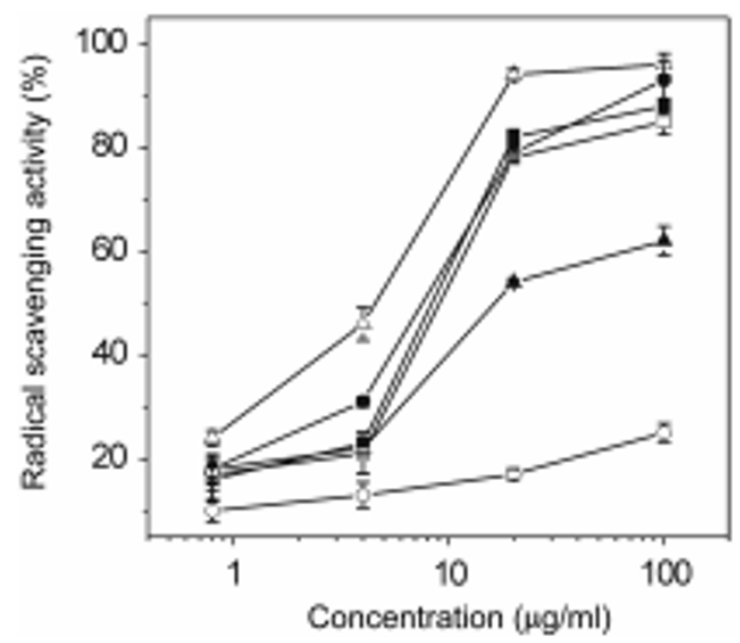

Figure 1. DPPH radical scavenging activity of total extracts and fractions of Smilax china root. Each experiment was performed at least 3 times and data are expressed as average percent change from control \pm S.D. - -Total extracts, $\bigcirc$-Hexane fractions, $\Delta$-Dichloromethane fractions, $\triangle$-Ethyl acetate fractions, $\mathbf{\square}$-Butanol fractions and $\square$-Water fractions. peroxidation. The DPPH radical scavenging activities of ME and SEF are presented in Figure 1. All samples showed the DPPH radical scavenging activity in a dosedependent manner. ME of Smilax china root showed relatively high DPPH radical scavenging activity, with an average $I_{50}$ value of $7.4 \mu \mathrm{g} / \mathrm{ml}$. The $D P P H$ radical scavenging activity of SEF samples was found to be in the order of ethyl acetate, butanol and water fractions, with $\mathrm{IC}_{50}$ values of $4.6,8.7$ and $9.6 \mu \mathrm{g} / \mathrm{ml}$, respectively. The DPPH free radical scavenging activity of hexane and dichloromethane fractions was not significant. $I_{50}$ values of hexane and dichloromethane fractions were $>100$ and $16 \mu \mathrm{g} / \mathrm{ml}$, respectively. The DPPH free radical scavenging activity of ME was comparable to that of ethyl acetate, butanol and water extracted fractions, which showed significantly high free radical scavenging activities in this study. Therefore, we used ME to investigate overall antioxidant activity of Smilax china root.

The effect of Smilax china on V79-4 cell proliferation
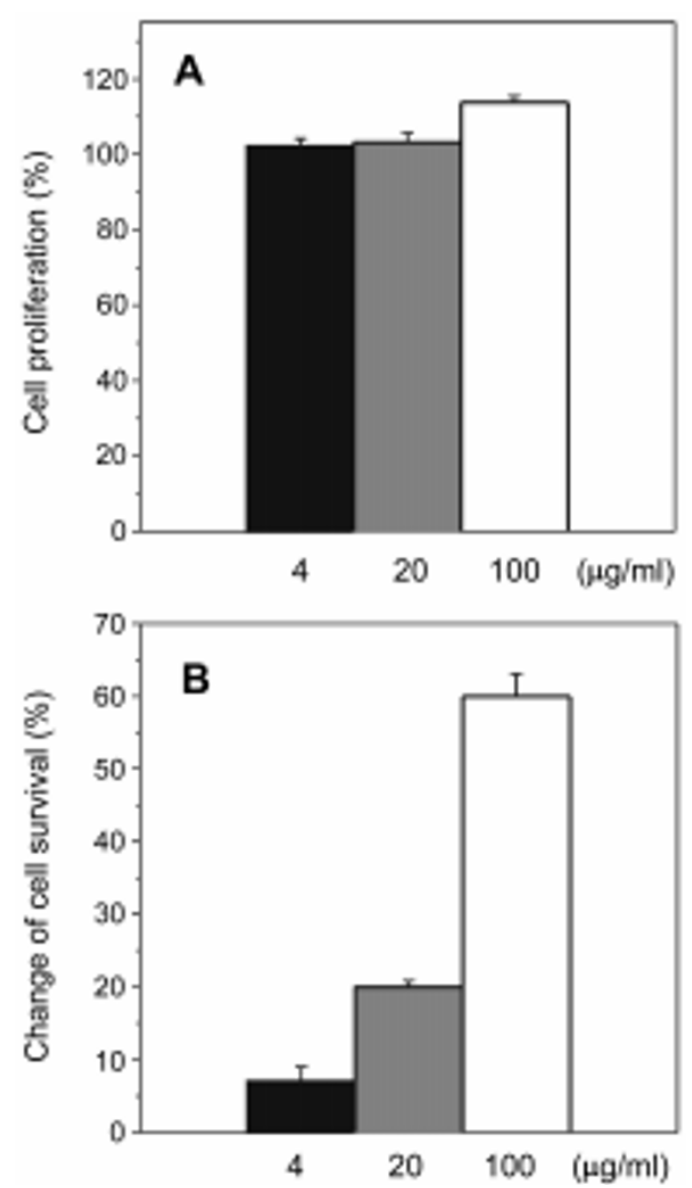

Figure 2. (A) Effect on cell proliferation of Smilax china root extracts in V794 cells. (B) Protective effect of total extracts of Smilax china root against $\mathrm{H}_{2} \mathrm{O}_{2}$-induced oxidative damage in V79-4 cells. Each experiment was performed at least 3 times and data are expressed as mean \pm S.D. (A) or average percent change from control \pm S.D. (B) Black, gray and white bars indicate 4,20 and $100 \mu \mathrm{g} / \mathrm{ml}$ of samples, respectively. 


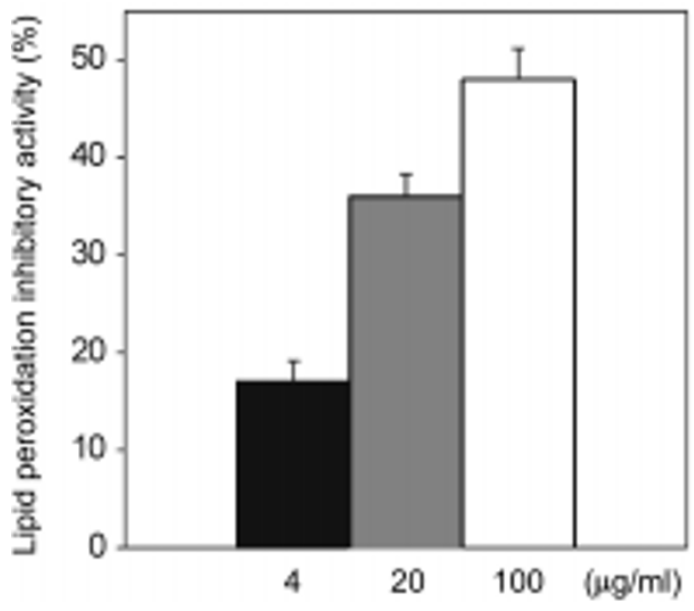

Figure 3. Lipid peroxidation inhibitory activity of total extracts of Smilax china root against $\mathrm{H}_{2} \mathrm{O}_{2}$-induced oxidative damage in V79-4 cells. Each experiment was performed at least 3 times and data are expressed as average percent change from control \pm S.D. Black, gray and white bars indicate 4,20 and $100 \mu \mathrm{g} / \mathrm{ml}$ of samples, respectively.

was evaluated by MTT assay. Smilax china treatment at concentration from 4 to $100 \mu \mathrm{g} / \mathrm{ml}$ caused slight stimulation of cell proliferation and did not affect any cell morphology. Thus, all subsequent experiments were carried out with ME concentration range of $4-100 \mu \mathrm{g} / \mathrm{ml}$.

Protective effect of ME on the cell viability was assessed by treating cells with ME for $1 \mathrm{~h}$ prior to the addition of $\mathrm{H}_{2} \mathrm{O}_{2}$. Control cells were treated with $\mathrm{H}_{2} \mathrm{O}_{2}$ in the presence of vehicle only. The final concentration of DMSO was below $0.1 \%$ in this study. There was no cytoprotective effect of DMSO at this concentration. The relative cell survival was determined $24 \mathrm{~h}$ later by the MTT assay. As shown in Figure 2B, treatment with ME of Smilax china root induced a dose-dependent increase in cell survival. Cell viability was increased definitively at a dose level of $100 \mu \mathrm{g} / \mathrm{ml} \mathrm{ME}$.

A possible effect of ME on lipid peroxidation in $\mathrm{H}_{2} \mathrm{O}_{2}-$ treated V79-4 cells was also assessed (Figure 3 ). ME did inhibit lipid peroxidation but a lot less than DPPH radical scavenging activity, with $\mathrm{IC}_{50}$ value of $>100 \mu \mathrm{g} /$ $\mathrm{ml}$.

\section{Effect of Methanol Extract of Smilax china root on antioxidant enzyme activity}

In order to investigate whether these antioxidant activities of Smilax china root extract are mediated by an increase in antioxidant enzymes, SOD, CAT and GPX activities in $\checkmark$ 79-4 cells were examined following ME treatment (Figure 4). Treatment of cells with ME at doses of 4, 20 and $100 \mu \mathrm{g} / \mathrm{ml}$ induced 10,16 and $25 \%$ increase in SOD levels, respectively (Figure 4A). Increments of SOD activity in a dose dependent manner over ME concentration range of 4 to $100 \mu \mathrm{g} / \mathrm{ml}$ was detected. The activity of SOD in control cells untreated with ME
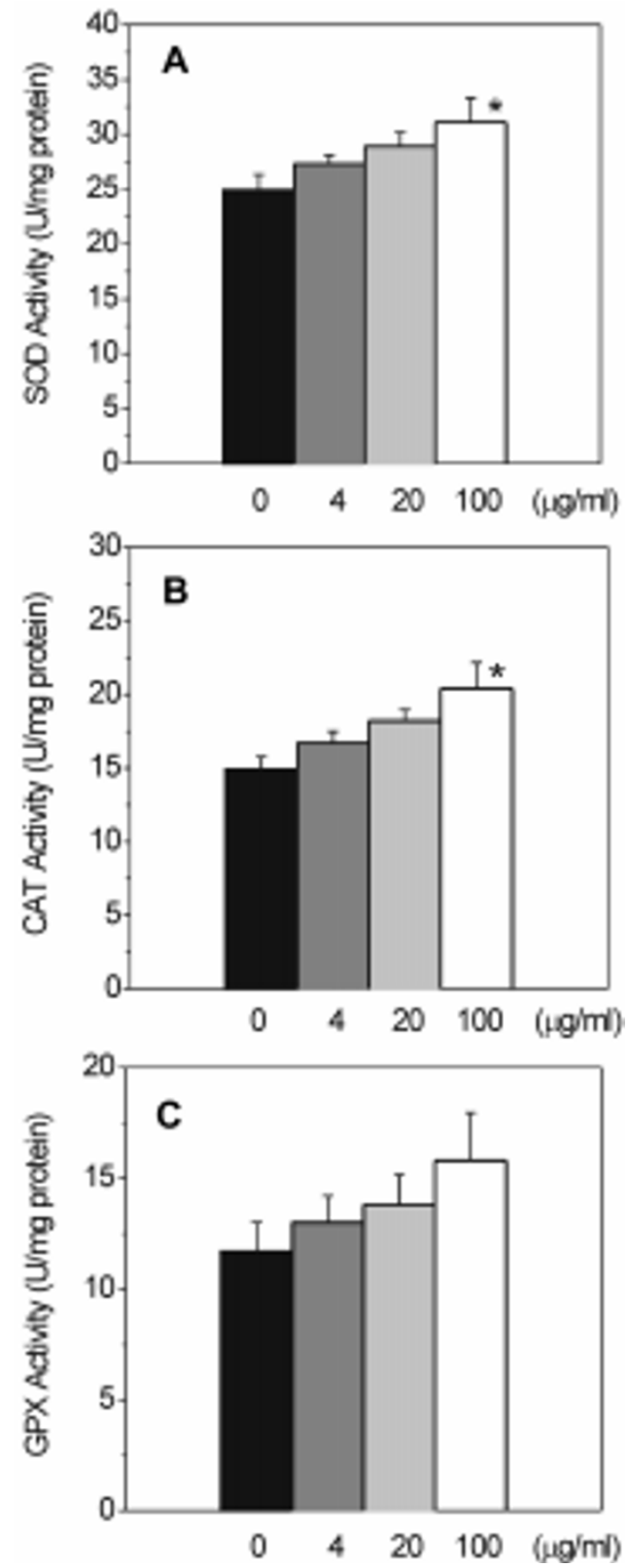

Figure 4. Effect of total extracts of Smilax china root on SOD (A), CAT (B) and GPX (C) activity in V79-4 cells. Each experiment was performed at least 3 times and data are expressed as average enzyme unit per mg protein \pm S.D. Black, gray, light gray, and white bars indicate $0,4,20$, and $100 \mu \mathrm{g} /$ $\mathrm{ml}$ of samples, respectively. ${ }^{*}$ statistically significant vs. control $(p<0.05)$.

was $24.9 \pm 1.5 \mathrm{U} / \mathrm{mg}$ protein. The relatively higher increment of CAT than SOD activities was observed when cells were treated with Smilax china root ME (Figure 4B). The CAT activity was also dosedependently increased upon exposure of cells to various ME concentrations. At doses of 4,20 and 100 $\mu \mathrm{g} / \mathrm{ml}$, ME activated CAT by 12,22 and $37 \%$, respectively. The CAT activity of control cells untreated with extracts was $14.9 \pm 1.9 \mathrm{U} / \mathrm{mg}$ protein. 
A similar increase of cellular GPX activity was found upon treatment of cells with ME (Figure 4C). ME treatment of cells with 4,20 and $100 \mu \mathrm{g} / \mathrm{ml}$ resulted increment of GPX activity by 11,18 and $35 \%$, respectively. The activity of GPX in control cells untreated with extracts was $11.7 \pm 1.3 \mathrm{U} / \mathrm{mg}$ protein.

\section{Discussion}

Beneficial effects of antioxidants are well known in scavenging reactive oxygen species (ROS) before or preventing oxidative damage from spreading, e.g., by interrupting the radical chain reaction of lipid peroxidation (Halliwell and Gutteridge, 1998). Many antioxidants are known to be present in plants, fruits and vegetables. Possible presence of antioxidant activity in many commonly used medicinal plants is not well understood. In this study, methanol extract (ME) of Smilax china root, a popular herbal medicinal plant, showed a dosedependent significant DPPH free radical scavenging activity in vitro. ME also enhanced viability in V79-4 cells exposed to $\mathrm{H}_{2} \mathrm{O}_{2}$. Treatment of cells with ME of Smilax china root increased the activity of cellular antioxidant enzymes; SOD, CAT and GPX. Thus, these results indicate that Smilax china root extract possesses considerable antioxidant activity. The antioxidant components in Smilax china root fractionated by series of various solvent extraction showed the most active fraction was in the hydrophilic solvents; water, methanol, ethyl acetate, and butanol.

Recent studies confirm the presence of antioxidant activity in a small number of medicinal plants. The Withania somifera (WS), the ancient Hindu system of medicine, was found to enhance the activities of SOD, CAT and GPX in rat brain frontal cortex and striatum (Bhattacharya et al., 2001). The extract of Amomum xanthoides, from the fruit of Amomum vilosum Lour induced inhibition of alloxan-induced ROS generation (Park et al., 2001). Blackberries, raspberries and strawberries are reported to possess potent ROOscavenging capacity (Wang and Jiao, 2000). Tea polyphenols such as epigallocatechin gallate (EGCG), epigallocatechin (EGC) and epicatechin gallate (ECG) are another antioxidants to react with peroxy radical and terminate lipid peroxidation chain reactions ( $\mathrm{Li}$ and Xie, 2000). The antioxidant properties of the wild growing sage species, Salvia reflexa hornem, were found retain scavenging activity of DPPH free radicals. (Malencic et al., 2000). Effect of the fresh leaf pulp extract of Aloe vera was effective in inducing SOD and CAT activities in mice (Singh et al., 2000). Treatment with Aloe vera caused a decrease in malondialdehyde (MDA) formation and the activity of lactate dehydrogenase in the liver. Kim et al. (1996) found ginsenoside $\mathrm{Rb}_{1}$, a major saponin from Panax ginseng, was able to prevent lipid peroxidation.

Taken together, an increasing body of evidence suggests that many plants have antioxidant activities that could be therapeutically beneficial.

The activities of cellular antioxidant enzymes (SOD, CAT, GPX) are modulated in various disease states by the abundance of free radical species (Halliwell and Gutteridge, 1998). Thus, maintaining the balance between the rate of generation of radicals and scavenging of radicals is an essential part of biological homeostasis. It is of particular interest to note that SOD catalyzes the breakdown of $\mathrm{O}_{2}$ to $\mathrm{O}_{2}$ and $\mathrm{H}_{2} \mathrm{O}_{2}$, prevents formation of $\mathrm{OH}^{-}$and has hence been implicated as an essential defense against the potential toxicity of oxygen. The ROS scavenging activity of SOD is effective only when it is followed by the actions of CAT and GPX, because the dismutase activity of SOD generates $\mathrm{H}_{2} \mathrm{O}_{2}$, which needs to be further scavenged by CAT and GPX. Extracts of Smilax china root activated CAT and GPX to a greater extent than SOD. Taken together, these results also suggest that the antioxidant activity of Smilax china root extract may lie in its ability to degrade $\mathrm{H}_{2} \mathrm{O}_{2}$ and other peroxides.

In conclusion, extracts from Smilax china root have high levels of DPPH radical scavenging activity, inhibit lipid peroxidation, promote cell viability, and enhance the effects of various antioxidant enzymes. These findings strongly suggest that extracts of Smilax china root have potential chemoprotective activity against oxidative stress.

Demonstration of the high levels of antioxidant components present in Smilax china root extract will provide scientific base for further investigation of unknown components.

\section{Acknowledgements}

Korea Research Foundation Grant (KRF-98-019-F00073) supported this study. S. E. Lee is a post-doctoral researcher and E. M. Ju is a graduate fellow of Brain Korea 21 program supported by Ministry of Education, Korea.

\section{References}

Beauchamp C, Fridovich I. Assays of superoxide dismutase. Anal Biochem 1971;44:276-87

Bhattacharya A, Ghosal S, Bhattacharya SK. Anti-oxidant effect of Withania somnifera glycowithanolides in chronic footshock stress-induced perturbations of oxidative free radical scavenging enzymes and lipid peroxidation in rat frontal cortex and striatum. J Ethnopharmacol 2001;74:1-6

Blake DR, Allen RE, Lunee J. Free radicals in biological systems: a review oriented to the inflammatory process. $\mathrm{Br}$ Med Bull 1987;43:371-85 
Blosi MS. Antioxidant determinations by the use of a stable free radical. Nature 1958;181:1199-200

Borek $\mathrm{C}$. Free radical processes in multistage carcinogenesis. Free Radic Res Commu 1991;12:745-50

Bradford MM. A rapid and sensitive method for the quantitation of microgram quantities of protein utilizing the principle of protein-dye binding. Anal Biochem 1976;72:248-54

Brown JE, Rice-Evans CA. Luteolin-rich artichoke extract protects low density lipoprotein from oxidation in vitro. Free Radic Res 1998;29:247-55

Cao G, Sofic E, Prior RL. Antioxidant and prooxidant behaviour of flavonoids: Structure-activity relationships. Free Radic Biol Med 1996;22:749-60

Deiana M, Aruoma OI, Bianchi M, Halliwell B, Aeschbach R, Corongiu FP. Inhibition of peroxinitrite-dependent DNA base modification and tyrosine nitration by the extra virgin olive oilderived antioxidant hydroxytyrosol. Free Radic Biol Med 1999; 26:762-69

Duh PD, Yen WJ, Du PC, Yen GC. Antioxidant activity of mung bean hulls. J Am Oil Chem Soc 1997;74:1059-63

Finkel T, Holbrook NJ. Oxidants, oxidative stress and the biology of ageing. Nature 2000;408:239-47

Gohil K, Moy RK, Farzin S, Maguire JJ, Packer L. mRNA expression profile of a human cancer cell line in response to Ginkgo biloba extract: induction of antioxidant response and the Golgi system. Free Radic Res 2000;33:831-49

Halliwell B, Gutteridge JMC. Free Radicals in Biology and Medicine. 3rd Ed., 1998, Oxford University

Hansen MB, Nielsen SE, Berg K. Re-examination and further development of a precise and rapid dye method for measuring cell growth/cell kill. J Immunol Methods 1989;119:203-10

Keum YS, Park KK, Lee JM, Chun KS, Surh YJ. Antioxidant and anti-tumor promoting activities of the methanol extract of heat-processed ginseng. Cancer Lett 2000;150:41-48

Kim JS, Oh JH, Lee DW, Park HJ, Park DK. Effect of ginsenoside $\mathrm{Rb}_{1}$ on lipid peroxidation and neurotoxicity induced by MPTP in liver and brain of mouse. Exp Mol Med 1996;28:199-205

Kitts DD, Yuan YV, Wijewickreme AN, Hu C. Antioxidant properties of a North American gingseng extract. Mol Cell Biochem 2000;203:1-10

Lee $\mathrm{H}$, Lin JY. Antimutagenic activity of extracts from anticancer drugs in Chinese medicine. Mutat Res 1988;204:229-
34

Li C, Xie B. Evaluation of the antioxidant and pro-oxidant effects of tea catechin oxypolymers. J Agric Food Chem 2000;48:6362-66

Malencic D, Gasic C, Popovic M, Boza P. Screening for antioxidant properties of Salvia reflexa hornem. Phytother Res 2000; $14: 546-48$

McCord JM, Fridovich I. Superoxide dismutase: An enzymic function for erythrocuprein (hemocuprein). J Biol Chem 1969; 244:6049-55

Ohkawa H, Ohishi N, Yagi K. Assay for lipid peroxide in animal tissues by thiobarbituric acid reaction. Anal Biochem 1979;95:351-58

Paglia DE, Valentine WN. Studies on the quantitative and qualitative characterization of erythrocyte glutathione peroxidase. J Lab Clin Med 1967;70:158-64

Park BH, Park JW. The protective effect of Amomum xanthoides extract against alloxan-induced diabetes through the suppression of NFKB activation. Exp Mol Med 2001;33:6468

Richardson SJ. Free radicals in the genesis of Alzheimer's disease. Ann NY Acad Sci 1993;695:73-76

Roedig-Penman A, Gordon MH. Antioxidant properties of catechins and green tea extracts in model food emulsions. J Agric Food Chem 1997;45:4267-70

Singh RP, Dhanalakshmi S, Rao AR. Chemomodulatory action of Aloe vera on the profiles of enzymes associated with carcinogen metabolism and antioxidant status regulation in mice. Phytomed 2000;7:209-19

Song JH, Kwon HD, Lee WK, Park IH. Antimicrobial activity and composition of extract from Smilax china root. J Korean Soc Food Sci Nutr 1998;27:574-84

Wang $\mathrm{H}$, Cao G, Prior RL. Total oxidant capacity of fruits. J Agric Food Chem 1996;44:701-705

Wang SY, Jiao H. Correlation of antioxidant capacities to oxygen radical scavenging enzyme activities in blackberry. J Agric Food Chem 2000;48:5672-76

Wang SY, Jiao $\mathrm{H}$. Scavenging capacity of berry crops on superoxide radicals, hydrogen peroxide, hydroxyl radicals, and singlet oxygen. J Agric Food Chem 2000;48:5677-84

Witztum JL. The role of oxidized low density lipoproteins in atherogenesis. Br Heart J 1993;69:12-14 